\title{
EFFECTS OF CADMIUM ON GROWTH AND THE UPTAKE OF CADMIUM AND MICRONUTRIENTS BY TOBACCO (NICOTIANA TABACUM L.) CULTIVARS
}

\author{
KINAY, A. ${ }^{1^{*}}-$ ERDEM, $\mathrm{H}^{2}$ \\ ${ }^{1}$ Department of Field Crops, Faculty of Agriculture, Gaziosmanpasa University, 60240 Tokat, \\ Turkey \\ ${ }^{2}$ Departement of Soil Science and Plant Nutrition, Faculty of Agriculture, Gaziosmanpasa \\ University, 60240 Tokat, Turkey \\ *Corresponding author \\ e-mail: ahmetkinay@gmail.com; phone: +90-356-252-1616/2117
}

(Received $28^{\text {th }}$ May 2019; accepted $9^{\text {th }}$ Sep 2019)

\begin{abstract}
Tobacco (Nicotiana tabacum L.) can accumulate higher concentrations of cadmium (Cd). However, genotypic differences of tobacco cultivars in $\mathrm{Cd}$ uptake and their responses to Cd toxicity have not been thoroughly investigated. This study was conducted to determine the resistance of four tobacco cultivars to $\mathrm{Cd}$ toxicity under greenhouse conditions. Four doses of $\mathrm{Cd}\left(0,5,10\right.$ and $20 \mathrm{mg} \mathrm{kg}^{-1}$ soil) were used to test the resistance of tobacco cultivars. Increasing the $\mathrm{Cd}$ applications significantly $(\mathrm{P}<0.01)$ decreased the shoot dry matter yields of genotypes, while shoot $\mathrm{Cd}$ concentration and content significantly $(\mathrm{P}<0.01)$ increased. The highest decrease in dry matter under the highest $\mathrm{Cd}(\mathrm{Cd} 20)$ treatment was in Özbaş (58.5\% reduction), Birlik/124 (52.4\% reduction) and Canik190/5 (51.1\% reduction) cultivars, while the lowest decrease was in Xanthi/81 (44.6\% reduction) cultivar. The amount of $\mathrm{Cd}$ removed from soil was significantly different among the tobacco cultivars. The highest Cd uptake was obtained in Cd20, while the lowest was in Xanthi/81 (395.2 $\left.\mu \mathrm{g} \mathrm{Cd} \mathrm{plant}^{-1}\right)$ and Canik190/5 (232.6 $\mu \mathrm{g}$ $\mathrm{Cd}_{\text {plant }}{ }^{-1}$ ) cultivars, respectively. The results revealed that Canik190/5 cultivar removes lower Cd compared to the other cultivars, whereas Cd uptake of Xanthi/81 cultivar is higher, thus is considered more resistant to $\mathrm{Cd}$ toxicity than other cultivars.
\end{abstract}

Keywords: Nicotiana tabacum L., heavy metal, pollution, soil, yield

\section{Introduction}

Cadmium (Cd), having a toxic effect on all living organisms, is one of the most dangerous heavy metal pollutants in the ecosystem (Mishra et al., 2019). The major sources of $\mathrm{Cd}$ in soils are geological parent material and inputs from human activities. Extraneous sources of cadmium are phosphorus fertilizers (54 to 58\%), atmospheric storage (39 to $41 \%$ ) and sewage sludge and farm manure applications (2 to 5\%) (Cheng et al., 2014). The Cd uptake ratio of plants is high, due to its high-water solubility and mobility in soil compared to the other metals. Therefore, $\mathrm{Cd}$ is considered to be the most dangerous heavy metal accumulated in soils. The $\mathrm{Cd}$ causes many physiological changes due to changes in nitrogen and carbohydrate metabolism in plants. Cadmium inactivates the enzymes in -SH groups of proteins, closes stomata, causes water loss by transpiration and deterioration of chlorophyll biosynthesis (Sharma et al., 2019). The severity of heavy metal stress of plants varies depending on the environmental factors and the growth stage of plants (Stolt et al., 2003). The Cd resistance, uptake and transport of $\mathrm{Cd}$ in plant significantly vary among plant species. Grant et al. (1998) indicated that $\mathrm{Cd}$ concentrations of wheat, pea, maize and tobacco grown in the same solution culture were considerably different, and wheat contained lower $\mathrm{Cd}$ 
concentration than the others. The magnitude of $\mathrm{Cd}$ accumulation and location of $\mathrm{Cd}$ in plants are major determinants of the plant resistance to $\mathrm{Cd}$ toxicity (Obata and Umebayashi, 1993; Quezada-Hinojosa et al., 2015). The responses of plant species and even between cultivars of a particular species to Cd toxicity considerably differ due to the prominent genetic variability among the different cultivars. The results reported by Erdem et al. $(2012,2017)$ for tobacco, Socha et al. (2015) for soybean, Wang et al. (2016) for maize, Zhang et al. (2002) for wheat and Zorrig et al. (2019) for lettuce clearly point out the effects of genetic variation in Cd uptake of plants. Several metaltolerance mechanisms were introduced to explain the responses minimizing the adverse effects of heavy metal exposure. The Cd immobilization at the cell wall is the first prevention mechanism to prevent from excess Cd effect (Rizwan et al., 2016). Preventing the penetration of $\mathrm{Cd}$ into the cytosol, complexation of $\mathrm{Cd}$ with peptides or proteins to form phytochelatins and metallothioneins, compartmentalizing of $\mathrm{Cd}$ within vacuoles, and improving the antioxidative defense systems are major causes defined to explain the Cd detoxification in plants (Kirkham, 2006). Tobacco is one of the most common substances consumed for pleasure in the world. However, smoke of tobacco products is the most prevalent means of Cd reception of human, especially for smokers (Willers et al., 2005). Tobacco is known as an efficient Cd accumulator (Lugon-Moulin et al., 2004). Therefore, studies on investigating the effects of different $\mathrm{Cd}$ concentrations on $\mathrm{Cd}$ uptake of the commonly grown tobacco cultivars are needed. Determining the genetic variation of tobacco cultivars in $\mathrm{Cd}$ accumulation and uptake mechanisms are also important for the plant breeders. Research, particularly, focusing on metal uptake of international and local commercial tobacco cultivars used for tobacco products is missing.

This study was carried out to investigate the effects of different Cd concentrations on the growth of various tobacco cultivars, to determine the responses of tobacco cultivars in terms of $\mathrm{Cd}$ concentration and uptake, and to comprehend the interactions between $\mathrm{Cd}$ and $\mathrm{Fe}, \mathrm{Zn}, \mathrm{Cu}$ and $\mathrm{Mn}$ in tobacco plants.

\section{Materials and methods}

\section{Materials}

A pot experiment using Özbas, Canik190/5, Xanthi/81 and Birlik/124 tobacco cultivars was carried out at the greenhouse in Gaziosmanpasa University, Tokat, Turkey. Some characteristics of the genotypes used in the experiment are given in Table 1. The soil, used in the pot experiment was sandy loam, high in $\mathrm{CaCO}_{3}$ content (11.8\%), slightly alkaline in $\mathrm{pH}(8.01)$, low in organic matter content $(0.89 \%)$ and $\mathrm{Zn}$ concentration $\left(0.38 \mathrm{mg} \mathrm{kg}^{-1}\right)$, sufficient in $\mathrm{Fe}, \mathrm{Mn}$ and $\mathrm{Cu}$ concentrations $(6.65,3.97$ and $\left.1.98 \mathrm{mg} \mathrm{kg}^{-1}\right)$, respectively), and low in Cd concentration $\left(0.004 \mathrm{mg} \mathrm{kg}^{-1}\right)$.

Table 1. Some characteristics of tobacco genotypes used in the experiment (Peksüslü, 1998)

\begin{tabular}{c|c|c|c|c}
\hline Genotypes & Flowering & Plant height $(\mathbf{c m})$ & Number of leaves & Quality degree \\
\hline Özbaş & Medium late & $60-85$ & $35-40$ & Medium \\
Canik190/5 & Early & $75-95$ & $32-35$ & Medium \\
Xanthi/81 & Medium late & $65-105$ & $30-32$ & High \\
Birlik/124 & Medium late & $85-125$ & $40-44$ & High \\
\hline
\end{tabular}




\section{Methods}

\section{Experiment}

Greenhouse experiment was carried out in Field Research Centre of Tokat Gaziosmanpasa University located at $40^{\circ} 20^{\prime} 02.19^{\prime \prime} \mathrm{N}$ latitude and $36^{\circ} 28^{\prime} 30.11^{\prime \prime} \mathrm{E}$ longitude and $623 \mathrm{~m}$ above sea level, Tokat Province in middle Black Sea region of Turkey. The pot experiment was laid in a randomized plot design with three replications. Tobacco seedlings in a 4-leaf stage were transferred to the plastic pots filled with $2.75 \mathrm{~kg}$ sandy loam soil. Air-dried soil, prior to filling the pots, was homogeneously mixed with a fertilizer solution containing $250 \mathrm{mg} \mathrm{N} \mathrm{kg} \mathrm{soil}^{-1}$ as $\mathrm{Ca}\left(\mathrm{NO}_{3}\right)_{2} .4 \mathrm{H}_{2} \mathrm{O}, 100 \mathrm{mg} \mathrm{P} \mathrm{kg}^{-1}$ soil as $\mathrm{KH}_{2} \mathrm{PO}_{4}, 2.0 \mathrm{mg} \mathrm{Fe} \mathrm{kg}^{-1}$ soil as Fe-EDTA and $2.0 \mathrm{mg} \mathrm{Zn} \mathrm{kg}{ }^{-1}$ soil as $\mathrm{ZnSO}_{4} .7 \mathrm{H}_{2} \mathrm{O}$. The treatments were control $(\mathrm{Cd} 0), 5.0(\mathrm{Cd} 5), 10$ $(\mathrm{Cd} 10)$ and $20(\mathrm{Cd} 20) \mathrm{mg} \mathrm{Cd} \mathrm{kg}^{-1}$, and each treatment was replicated three times. The $\mathrm{Cd}$ was applied as a solution containing $3\left(\mathrm{CdSO}_{4}\right) \cdot 8 \mathrm{H}_{2} \mathrm{O}$. Pots were watered as needed using deionized water. At 42 days after the transplanting of seedlings, leaves were harvested when the $\mathrm{Cd}$ toxicity symptoms (decline in growth and chlorosis in leaves) were observed (Fig. 1). The leaves were dried in an oven at $70{ }^{\circ} \mathrm{C}$ till constant weight. Dry weights (DW) of leaves were expressed as g DW of plants. Dried plant materials were powdered and then digested in a microwave oven using $2 \mathrm{ml}$ of $35 \% \mathrm{H}_{2} \mathrm{O}_{2}$ and $5 \mathrm{ml}$ of $65 \% \mathrm{HNO}_{3}$. The $\mathrm{Cd}, \mathrm{Fe}, \mathrm{Zn}, \mathrm{Cu}$, and $\mathrm{Mn}$ concentrations were determined by inductively coupled plasma atomic emission spectroscopy (Varian Vista) (Bataglia et al., 1978). The Cd content of plant material was calculated by multiplying the dry weight of shoot by the concentration of $\mathrm{Cd}$. The measurements of the metal concentrations were cross-checked by using the reference leaf samples of the National Institute of Standards and Technology (Gaithersburg, MD, USA).

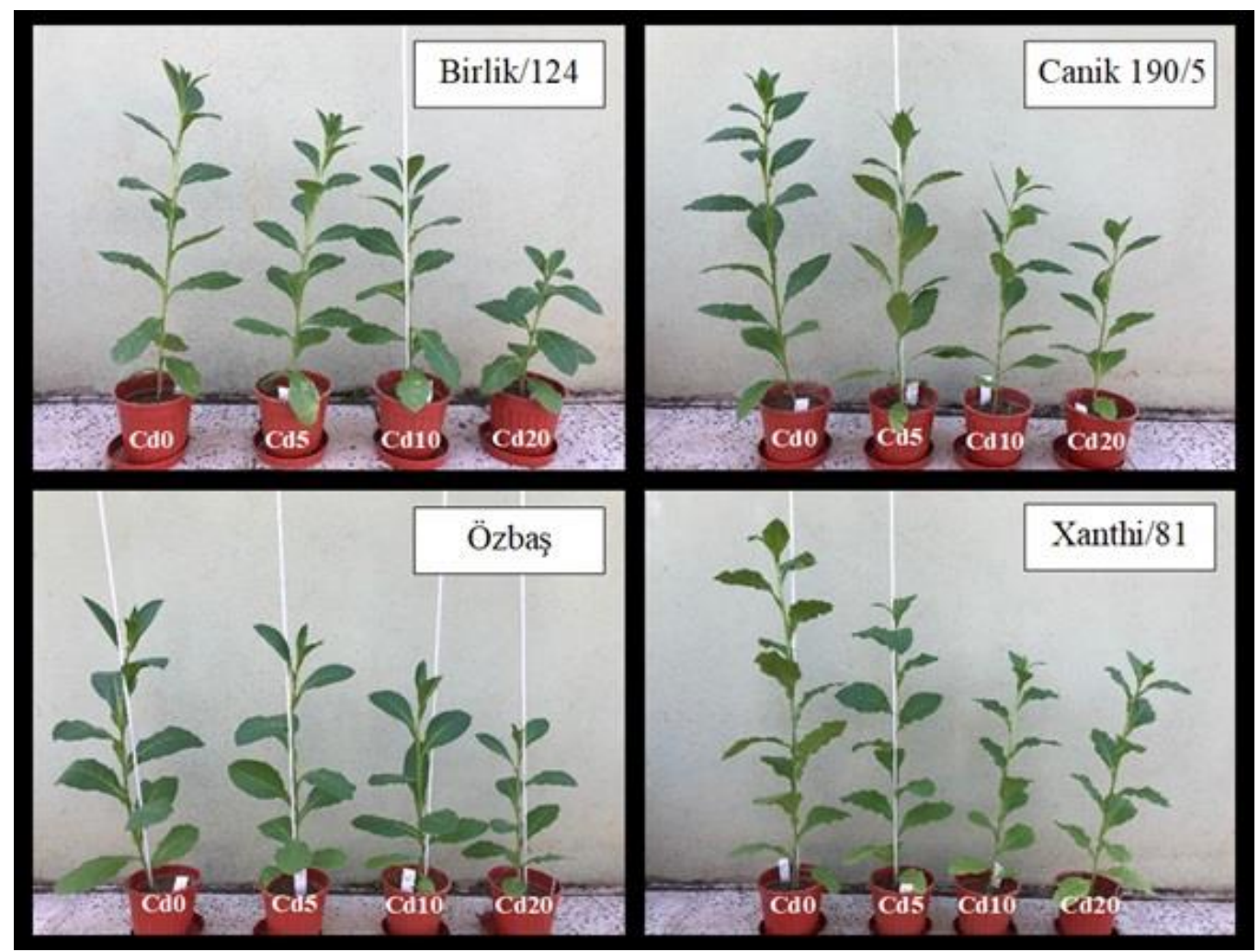

Figure 1. Effects of increasing doses of cadmium on tobacco genotypes 


\section{Statistical analyses}

Analyses of variance (ANOVA) were performed to test the Cd dose effects on element concentrations and content of four different tobacco cultivars and on dry matter yield. The means were compared with Duncan's homogeneity test to determine whether the average concentrations and content of tobacco grown in the treated pots differed from those of tobacco grown in the control pots. The dose effect was considered significant when the Pvalue lower than 0.05 . The statistical analyses were performed using the MSTAT-C statistical software.

\section{Results and discussion}

\section{Effect of cadmium on shoot dry matter yield, Cd concentration and Cd content}

The increasing $\mathrm{Cd}$ doses significantly $(\mathrm{P}<0.01)$ reduced the shoot dry matter yield of four tobacco cultivars (Table 2). The highest decrease in dry matter yield with increasing Cd dose was observed in Özbaş, Birlik/124, and Canik190/5 cultivars respectively, and the lowest was in Xanthi/81 cultivar. The dry matter yield of Özbaş cultivar in control treatment ( $0 \mathrm{mg} \mathrm{Cd} \mathrm{kg}^{-1}, \mathrm{Cd} 0$ ) was $6.90 \mathrm{~g}_{\text {plant }}{ }^{-1}$ which reduced to $2.87 \mathrm{~g}$ plant $^{-1}$ (58.5\% reduction) with $\mathrm{Cd} 20$ application, whereas dry matter yield of Xanthi/81 cultivar was $7.63 \mathrm{~g} \mathrm{plant}^{-1}$

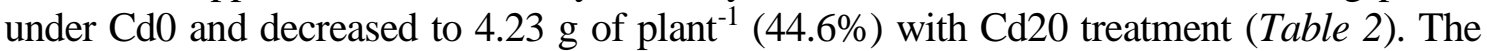
results of dry matter yield revealed that the Xanthi/81 is the least affected genotype from $\mathrm{Cd}$ toxicity. In a similar study conducted under greenhouse conditions testing five $\mathrm{Cd}$ doses $(0$, 100, 200 and $300 \mathrm{ppm}$ ) using 17 different tobacco cultivars, dry matter yields of cultivars significantly decreased with increasing Cd doses. However, the decrease in dry matter yield was significantly different among genotypes. The highest decrease in dry matter yield was reported in Connecticut (21\% reduction), Drama (19\% reduction), Myrodata Agryniou (18\% reduction) and Katerini 53 (5\% reduction) genotypes respectively, while the lowest decrease was obtained in Katerini 53 (5\% reduction) and Argyroudis genotypes (Vasiliadou and Dordas, 2009).

Erdem et al. (2017) reported a significant decrease in dry matter yield of Xhanti 2A

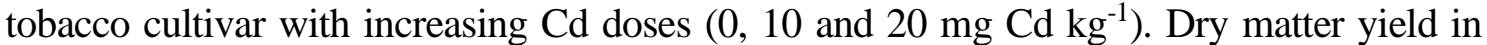
Cd20 (1.48 g of plant $\left.{ }^{-1}\right)$ treatment was $47.5 \%$ lower compared to the control $\left(2.82 \mathrm{~g} \mathrm{plant}^{-1}\right)$. In another study conducted with maize, a significant decrease in shoot dry matter yield was reported with increasing $\mathrm{Cd}$ doses. The reduction in shoot dry matter yield was $11.9 \%$ with $10 \mathrm{mg} \mathrm{Cd} \mathrm{kg}^{-1}$ and $23.5 \%$ with $20 \mathrm{mg} \mathrm{Cd} \mathrm{kg}^{-1}$ treatment (Khurana and Jhanji, 2014). The decrease in dry matter yield with Cd treatment was attributed to the phytotoxic effect of $\mathrm{Cd}$ (Pereira et al., 2011). Cadmium toxicity negatively affects the photosynthesis of plants by inhibiting the activities of photosynthetic enzymes involved in Kalvin cycle and chlorophyll biosynthesis and consequently results in a decrease in dry matter yield (Sun et al., 2017).

Cadmium can be easily transferred to the green parts of plants following the taken up by roots. The mobility of $\mathrm{Cd}$ in soils is higher than other heavy metals ( $\mathrm{Mn}, \mathrm{Zn}, \mathrm{Mo}$ and Se), thus can be easily taken up by many plant species (Moral et al., 2002). Therefore, a positive relationship was often reported between the increasing doses of $\mathrm{Cd}$ application and shoot $\mathrm{Cd}$ concentration and content. Shoot $\mathrm{Cd}$ concentrations and content of four tobacco cultivars were significantly $(\mathrm{P}<0.01)$ increased with increasing $\mathrm{Cd}$ application to the soil (Table 2). The lowest shoot $\mathrm{Cd}$ concentration under $\mathrm{Cd} 20$ treatment was obtained for Canik190/5 (79.8 $\left.\mathrm{mg} \mathrm{kg}^{-1}\right)$ and the highest Cd concentration was for Özbaş $\left(117.5 \mathrm{mg} \mathrm{kg}^{-1}\right)$ cultivars (Table 2). 
Table 2. The effects of increasing $C d$ doses on dry matter yield, shoot $C d$ concentration and content of four different tobacco cultivars

\begin{tabular}{|c|c|c|c|c|c|}
\hline Cultivar & $\begin{array}{l}\text { Cd doses } \\
\left(\mathrm{mg} \mathrm{kg}^{-1}\right)\end{array}$ & $\begin{array}{l}\text { Shoot dry } \\
\text { matter** }^{* *} \\
\left(\text { g plant }^{-1}\right)\end{array}$ & $\begin{array}{c}\text { Decrease in } \\
\text { shoot dry } \\
\text { matter }(\%) \\
\end{array}$ & $\begin{array}{c}\text { Shoot Cd } \\
\text { concentration** } \\
\left(\mathbf{m g ~ k g}^{-1}\right)\end{array}$ & $\begin{array}{c}\text { Shoot } \mathbf{C d} \\
\text { content }^{* *} \\
\left(\mu \text { p plant }^{-1}\right)\end{array}$ \\
\hline \multirow{5}{*}{ Özbaş } & 0 & $6,90^{\mathrm{a}}$ & - & $0,39^{\mathrm{d}}$ & $2,70^{c}$ \\
\hline & 5 & $4,97^{\mathrm{b}}$ & 27,9 & $47,6^{\mathrm{c}}$ & $237,3^{\mathrm{b}}$ \\
\hline & 10 & $4,11^{\mathrm{bc}}$ & 40,5 & $65,0^{\mathrm{b}}$ & $260,0^{\mathrm{ab}}$ \\
\hline & 20 & $2,87^{\mathrm{c}}$ & 58,5 & $117,5^{\mathrm{a}}$ & $337,3^{\mathrm{a}}$ \\
\hline & Average & $4,71^{\mathrm{B}}$ & - & $57,4^{\mathrm{B}}$ & $209,3^{\mathrm{AB}}$ \\
\hline \multirow{5}{*}{ Canik190/5 } & 0 & $5,99^{\mathrm{a}}$ & - & $0,34^{\mathrm{d}}$ & $2,05^{\mathrm{b}}$ \\
\hline & 5 & $5,51^{\mathrm{ab}}$ & 8,0 & $42,9^{\mathrm{c}}$ & $238,5^{\mathrm{a}}$ \\
\hline & 10 & $4,03^{\mathrm{bc}}$ & 32,7 & $55,4^{\mathrm{b}}$ & $222,7^{\mathrm{a}}$ \\
\hline & 20 & $2,93^{\mathrm{c}}$ & 51,1 & $79,8^{\mathrm{a}}$ & $232,6^{\mathrm{a}}$ \\
\hline & Average & $4,62^{B}$ & - & $44,6^{D}$ & $173,9^{\text {B }}$ \\
\hline \multirow{5}{*}{ Xanthi/81 } & 0 & $7,63^{\mathrm{a}}$ & - & $0,35^{\mathrm{d}}$ & $2,62^{\mathrm{c}}$ \\
\hline & 5 & $5,68^{b}$ & 25,6 & $41,8^{c}$ & $239,1^{\mathrm{b}}$ \\
\hline & 10 & $4,37^{b}$ & 42,7 & $71,2^{\mathrm{b}}$ & $310,6^{\mathrm{ab}}$ \\
\hline & 20 & $4,23^{b}$ & 44,6 & $93,4^{\mathrm{a}}$ & $395,2^{\mathrm{a}}$ \\
\hline & Average & $5,48^{\mathrm{A}}$ & - & $51,7^{\mathrm{C}}$ & $236,9^{A}$ \\
\hline \multirow{5}{*}{ Birlik/124 } & 0 & $5,31^{\mathrm{a}}$ & - & $0,39^{\mathrm{d}}$ & $2,10^{\mathrm{c}}$ \\
\hline & 5 & $4,71^{\mathrm{ab}}$ & 11,2 & $52,1^{\mathrm{c}}$ & $243,2^{\mathrm{b}}$ \\
\hline & 10 & $3,69^{\mathrm{b}}$ & 30,5 & $84,8^{\mathrm{b}}$ & $312,9^{\mathrm{a}}$ \\
\hline & 20 & $2,53^{\mathrm{c}}$ & 52,4 & $112,4^{\mathrm{a}}$ & $284,1^{\mathrm{a}}$ \\
\hline & Average & $4,06^{B}$ & - & $62,4^{\mathrm{A}}$ & $210,6^{\mathrm{AB}}$ \\
\hline \multicolumn{2}{|c|}{ Cultivar*Cd dose } & ns & & $* *$ & $*$ \\
\hline
\end{tabular}

$* * p<0.01, * p<0.05$, ns: non significant; small letters: differences in genotypes in terms of cadmium doses; capital letters: differences between genotypes

The Cd uptake and accumulation considerably differ between plant species and genotypes of the same species (Grant et al., 1998). The differences in Cd uptake and accumulation among plant species are considered as the main factors in determining plant tolerance to Cd toxicity (Obata and Umebayashi, 1993). The results indicated that the Cd uptake of plants significantly different between the cultivars used in the experiment. The highest $\mathrm{Cd}$ uptake $\left(395.2 \mu \mathrm{g}\right.$ plant $\left.^{-1}\right)$ at $\mathrm{Cd} 20$ dose was in Xanthi/81 cultivar and the lowest was in Canik190/5 (232.6 $\left.\mu \mathrm{g} \mathrm{plant}^{-1}\right)$ (Table 2).

The results of shoot $\mathrm{Cd}$ concentration and content revealed that $\mathrm{Cd}$ uptake of Canik cultivar is lower than the other tobacco cultivars. On the other hand, the resistance level of Xanthi/81 cultivar to Cd toxicity is considered higher compared to the other three tobacco cultivars due to the lower decrease in dry matter yield and higher Cd uptake under the increased $\mathrm{Cd}$ application doses (Table 2; Fig. 2). The Cd resistance of Xanthi/81 cultivar could be related to the detoxification of heavy metals. Similar to the finding of the current study, many studies have indicated that most of the plant species are capable of tolerating high Cd concentrations in soil (Mench et al., 1989; Cieśliński et al., 1998; Rizwan et al., 2016). Plants can build up tissue tolerance at different levels when exposed to high $\mathrm{Cd}$ concentration. Khan et al. (1984) reported that $\mathrm{Cd}$ accumulates in the cell wall, whereas Vazquez et al. (1992) reported that Cd accumulates in the vacuole in a study conducted with bean plants. 


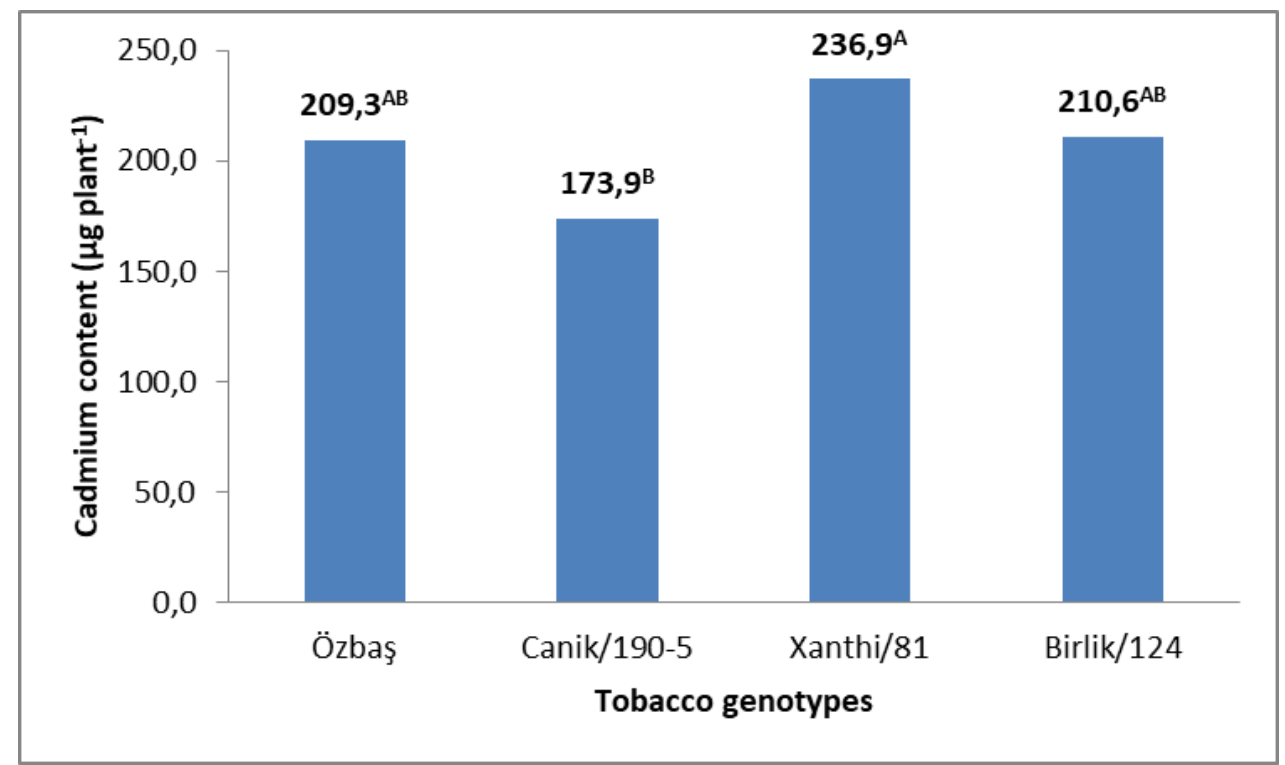

Figure 2. Average cadmium content ( $\mu \mathrm{g} C d$ plant $\left.^{-1}\right)$ of tobacco genotypes

\section{Effect of cadmium on shoot $\mathrm{Zn}, \mathrm{Fe}, \mathrm{Mn}$ and $\mathrm{Cu}$ concentrations}

Interaction of $\mathrm{Cd}$ with mineral nutrients (especially microelements) is an important effect of $\mathrm{Cd}$ toxicity in plants. The increasing $\mathrm{Cd}$ application dose to soil caused a decrease in the shoot $\mathrm{Zn}$ concentrations of 4 different tobacco varieties (Table 3). The decreases in shoot $\mathrm{Zn}$ concentration were insignificant for Canik190/5 and Birlik/124 cultivars, while it was significant $(\mathrm{P}<0.01)$ for Özbaş and Xanthi/81 cultivars. The $\mathrm{Zn}$ concentration of Xanthi/ 81 cultivar under Cd0 dose was $108.2 \mathrm{mg} \mathrm{kg}^{-1}$, which decreased to $74.5,68.7$ and $66.8 \mathrm{mg} \mathrm{kg}^{-1}$ at $\mathrm{Cd} 5, \mathrm{Cd} 10, \mathrm{Cd} 20$ doses, respectively. Vasiliadou and Dordas (2009) reported that increasing Cd application doses resulted in statistically significant reductions in shoot $\mathrm{Zn}$ concentrations $(-0.542 * * *)$ of 17 different tobacco cultivars. The decrease in $\mathrm{Zn}$ concentrations under increasing $\mathrm{Cd}$ doses may be linked to the antagonistic relationship between $\mathrm{Cd}$ and $\mathrm{Zn}$. Higher $\mathrm{Cd}$ uptake of plants grown under $\mathrm{Zn}$ deficiency can be attributed to the competition of $\mathrm{Cd}$ and $\mathrm{Zn}$, which have similar chemical properties, for absorption points on the membrane (Cakmak et al., 2000) and, increase in the membrane permeability (Cakmak and Marschner, 1988).

The shoot $\mathrm{Fe}$ concentrations of 4 different tobacco cultivars decreased with increasing $\mathrm{Cd}$ doses. The decrease was statistically significant in Canik190/5 while it was insignificant in the other three cultivars (Table 3). The Fe concentration of Canik190/5 cultivar was $64.8 \mathrm{mg} \mathrm{kg}^{-1}$ under control treatment, which decreased to 55.3, 54.8, and $57.4 \mathrm{mg} \mathrm{kg}^{-1}$ with $\mathrm{Cd} 5, \mathrm{Cd} 10$, and $\mathrm{Cd} 20$ treatments, respectively. Significant increases and decreases occurred in shoot Mn concentrations of the cultivars with $\mathrm{Cd}$ application. However, shoot $\mathrm{Cu}$ concentrations of all cultivars, particularly in the $\mathrm{Cd} 10$ and $\mathrm{Cd} 20$ treatments, decreased with $\mathrm{Cd}$ application (Table 3).

For example, shoot $\mathrm{Cu}$ concentration in $\mathrm{Cd} 0$ dose was $6.71 \mathrm{mg} \mathrm{kg}^{-1}$, which decreased to 6.56 in $\mathrm{Cd} 5$, while increased to 28.7 and $25.9 \mathrm{mg} \mathrm{kg}^{-1}$ in $\mathrm{Cd} 10$ and $\mathrm{Cd} 20$ doses, respectively (Table 3). Erdem et al. (2012) reported that the increasing doses of $\mathrm{Cd}$ resulted in a statistically significant $(\mathrm{P}<0.05)$ increase in shoot $\mathrm{Cu}$ concentration of tobacco plants. The results pointed out the importance of $\mathrm{Cu}$ absorption and/or translocation to the shoots, in contrast to the other essential micronutrients, under the 
high concentration of $\mathrm{Cd}$ in the root zone. In addition, shoot $\mathrm{Cu}$ concentrations of all tobacco cultivars used in the experiment were not affected by $\mathrm{Cd} 5$ treatments, whereas $\mathrm{Cd} 10$ and $\mathrm{Cd} 20$ treatments significantly affected the shoot $\mathrm{Cu}$ concentrations. Ramos et al. (2002) reported that increasing doses of Cd caused a decrease in shoot $\mathrm{Fe}, \mathrm{Zn}$ and $\mathrm{Cu}$ concentrations of lettuce plants grown under the water culture conditions, while an increase in Mn concentration. The results indicated a general decrease in the $\mathrm{Zn}, \mathrm{Fe}$ and Mn concentrations of tobacco plants with increasing the doses $\mathrm{Cd}$ application to soils. This situation reveals that the most important cause of the decrease in ion uptake of plants grown under $\mathrm{Cd}$ stress is the prevention of root growth and development due to damage of plant roots under Cd toxicity (Rizvan et al., 2016).

Table 3. The effects of increasing $\mathrm{Cd}$ doses on shoot $\mathrm{Zn}, \mathrm{Fe}, \mathrm{Mn}$ and $\mathrm{Cu}$ concentrations of 4 different tobacco cultivars

\begin{tabular}{|c|c|c|c|c|c|}
\hline Cultivar & $\begin{array}{l}\text { Cd doses } \\
\left(\mathrm{mg} \mathrm{kg}^{-1}\right)\end{array}$ & $\begin{array}{c}\mathbf{Z n}^{* *} \\
\left(\mathrm{mg} \mathrm{kg}^{-1}\right) \\
\end{array}$ & $\begin{array}{c}\mathrm{Fe}^{* *} \\
\left(\mathrm{mg} \mathrm{kg}^{-1}\right)\end{array}$ & $\begin{array}{c}\mathrm{Mn}^{\mathrm{ns}} \\
\left(\mathrm{mg} \mathrm{kg}^{-1}\right)\end{array}$ & $\begin{array}{c}\mathrm{Cu}^{* *} \\
\left(\mathrm{mg} \mathrm{kg}^{-1}\right)\end{array}$ \\
\hline \multirow{5}{*}{ Özbaş } & 0 & $82.5^{\mathrm{a}}$ & $71.8^{\mathrm{ns}}$ & 36.9 & $5.98^{\mathrm{b}}$ \\
\hline & 5 & $65.9^{\mathrm{ab}}$ & $58.8^{\mathrm{ns}}$ & 41.0 & $6.26^{\mathrm{b}}$ \\
\hline & 10 & $60.5^{\mathrm{b}}$ & $58.4^{\mathrm{ns}}$ & 41.3 & $29.5^{\mathrm{a}}$ \\
\hline & 20 & $68.7^{\mathrm{ab}}$ & $62.1^{\mathrm{ns}}$ & 39.5 & $26.6^{\mathrm{a}}$ \\
\hline & Average & $69.4^{\mathrm{AB}}$ & $62.8^{\mathrm{AB}}$ & 39.7 & 17.1 \\
\hline \multirow{5}{*}{ Canik190/5 } & 0 & $85.2^{\mathrm{ns}}$ & $64.8^{\mathrm{a}}$ & 38.8 & $6.16^{\mathrm{b}}$ \\
\hline & 5 & $73.3^{\mathrm{ns}}$ & $55.3^{\mathrm{b}}$ & 37.2 & $4.54^{\mathrm{b}}$ \\
\hline & 10 & $62.8^{\mathrm{ns}}$ & $54.8^{\mathrm{b}}$ & 33.6 & $28.3^{\mathrm{a}}$ \\
\hline & 20 & $60.3^{\mathrm{ns}}$ & $57.4^{\mathrm{ab}}$ & 34.5 & $27.7^{\mathrm{a}}$ \\
\hline & Average & $70.4^{\mathrm{AB}}$ & $58.1^{\mathrm{B}}$ & 36.0 & 16.7 \\
\hline \multirow{5}{*}{ Xanthi/81 } & 0 & $108.2^{\mathrm{a}}$ & $74.0^{\mathrm{ns}}$ & 38.8 & $4.92^{\mathrm{c}}$ \\
\hline & 5 & $74.5^{\mathrm{b}}$ & $60.0^{\mathrm{ns}}$ & 34.2 & $3.92^{\mathrm{c}}$ \\
\hline & 10 & $68.7^{\mathrm{b}}$ & $57.2^{\mathrm{ns}}$ & 39.1 & $28.7^{\mathrm{a}}$ \\
\hline & 20 & $66.8^{\mathrm{b}}$ & $65.8^{\mathrm{ns}}$ & 36.5 & $23.6^{\mathrm{b}}$ \\
\hline & Average & 79.6.$^{\mathrm{A}}$ & $64.2^{\mathrm{AB}}$ & 37.1 & 15.30 \\
\hline \multirow{5}{*}{ Birlik/124 } & 0 & $66.9^{\mathrm{ns}}$ & $78.3^{\text {ns }}$ & 39.6 & $6.71^{\mathrm{b}}$ \\
\hline & 5 & $60.7^{\mathrm{ns}}$ & $59.0^{\mathrm{ns}}$ & 38.2 & $6.56^{\mathrm{b}}$ \\
\hline & 10 & $52.9^{\mathrm{ns}}$ & $71.7^{\mathrm{ns}}$ & 35.5 & $28.7^{\mathrm{a}}$ \\
\hline & 20 & $58.1^{\mathrm{ns}}$ & $72.9^{\text {ns }}$ & 34.8 & $25.9^{a}$ \\
\hline & Average & $59.7^{\mathrm{B}}$ & $70.5^{\mathrm{A}}$ & 37.0 & 17.0 \\
\hline \multicolumn{2}{|c|}{ Cultivar x Cd dose } & ns & ns & ns & ns \\
\hline
\end{tabular}

$* * \mathrm{p}<0.01, * \mathrm{p}<0.05, \mathrm{~ns}$ : non significant; small letters: differences in genotypes in terms of cadmium doses; capital letters: differences between genotypes

\section{Conclusions}

Cadmium pollution in soils is a worldwide serious problem for sustainable agriculture and human health (Dumat et al., 2019). This study presents novel information about the effects of toxic $\mathrm{Cd}$ doses on the growth of tobacco cultivars, the amount of $\mathrm{Cd}$ uptake from the soil, and uptake of microelements. Shoot dry matter yields of tobacco cultivars significant $(\mathrm{P}<0.01)$ reduced with the increasing doses of 
Cd application to soil. The greatest reduction has occurred in Özbaş, Birlik/124 and Canik190/5 cultivars, while the lowest was in Xanthi/81 cultivar. The Cd concentration and content of shoots significantly $(\mathrm{P}<0.01)$ increased with the increase in $\mathrm{Cd}$ doses. The Xanthi/81 taken up the highest $\mathrm{Cd}$ concentration from soil under the highest $\mathrm{Cd}$ treatment (Cd20), while Canik190/5 cultivar removed lower Cd from soil compared to the other cultivars. The $\mathrm{Cd}$ treatments resulted in a decrease in shoot $\mathrm{Zn}$ and $\mathrm{Fe}$ concentrations of tobacco cultivars, while increases and decreases occurred for $\mathrm{Mn}$ concentrations. The $\mathrm{Cu}$ concentration of shoots significantly increased in $\mathrm{Cd} 10$ and Cd20 treatments. The results revealed that Canik190/5 cultivar uptakes lower Cd from the soil compared to the other three tobacco cultivars. In contrast, Xanthi/81 cultivar uptakes higher $\mathrm{Cd}$ from the soil, thus considered more resistant to $\mathrm{Cd}$ toxicity than other tobacco cultivars. The data obtained will contribute to the basic knowledge needed for further research on the genetic and biochemical basis of cadmium uptake of tobacco genotypes.

Conflict of interests. The authors have not declared any conflict of interests.

\section{REFERENCES}

[1] Bataglia, O. C., Teixeira, J. P. F., Furlani, P. R., Furlani, A. M. C., Gallo, J. R. (1978): Métodos de análise química de plantas. - IAC, Campinas.

[2] Cakmak, I., Marschner, H. (1988): Increase in membrane permeability and exudation in roots of zinc deficient plants. - J. Plant Physiol. 132(3): 356-361.

[3] Cakmak, I., Welch, R. M., Erenoğlu, B., Romheld,V., Norvell, W. A., Kochian, L. V. (2000): Influence of varied zinc supply on re-translocation of cadmium $\left({ }^{109} \mathrm{Cd}\right)$ and rubidium $\left({ }^{86} \mathrm{Rb}\right)$ applied on mature leaf of durum wheat seedlings. - Plant and Soil 219(12): 279-284.

[4] Cheng, K., Tian, H. Z., Zhao, D., Lu, L., Wang, Y., Chen, J., Huang, Z. (2014): Atmospheric emission inventory of cadmium from anthropogenic sources. - International Journal of Environmental Science and Technology 11(3): 605-616.

[5] Cieśliński, G., Van Rees, K. C. J., Szmigielska, A. M., Krishnamurti, G. S. R., Huang, P. M. (1998): Low-molecular-weight organic acids in rhizosphere soils of durum wheat and their effect on cadmium bioaccumulation. - Plant Soil 203(1): 109-117.

[6] Dumat, C., Pierart, A., Shahid, M., Khalid, S. (2019): Pollutants in urban agriculture. Bioremediation of Agricultural Soils 100: 61.

[7] Erdem, H., Kınay, A., Ozturk, M., Tutus, Y. (2012): Effect of cadmium stress on growth and mineral composition of two tobacco cultivars. - Journal of Food, Agriculture \& Environment 10(1): 965-969.

[8] Erdem, H., Kınay, A., Günal, E., Yaban, H., Tutuş, Y. (2017): The effects of biochar application on cadmium uptake of tobacco. - Carpathian Journal of Earth and Environmental Sciences 12(2): 447-456.

[9] Grant, C. A., Buckley, W. T., Bailey, L. D., Selles, F. (1998): Cadmium accumulation in crops. - Can. J. Plant Sci. 78(1): 1-17.

[10] Khan, D. H., Duckett, J. G., Frankland, B., Kirkham, J. B. (1984): An X-ray microanalytical study of the distribution of cadmium inroots of Zea mays L. - J. Plant Physiol. 115(1): 19-28.

[11] Khurana, M. P. S., Jhanji, S. (2014): Influence of cadmium on dry matter yield, micronutrient content and its uptake in some crops. - Journal of Environmental Biology 35(5): 865 . 
[12] Kirkham, M. B. (2006): Cadmium in plants on polluted soils. Effects of soil factors, hyperaccumulation, and amendments. - Geoderma 137(1-2): 19-32.

[13] Lugon-Moulin, N., Zhang, M., Gadani, F., Rossi, L., Koller, D., Krauss, M., Wanger, G. J. (2004): Critical review of the science and options for reducing cadmium in tobacco (Nicotiana tabacum L.) and other plants. - Adv. Agron. 83: 111-180.

[14] Mench, M., Tancogne, J., Gomez, A., Juste, C. (1989): Cadmium bioavailability to Nicotiana tabacum L., Nicotiana rustica L., and Zea mays L. grown in soil amended or not amended with cadmium nitrate. - Biology and fertility of soils 8(1): 48-53.

[15] Mishra, S., Bharagava, R. N., More, N., Yadav, A., Zainith, S., Mani, S., Chowdhary, P. (2019): Heavy Metal Contamination: An Alarming Threat to Environment and Human Health. - In: Sobti, R. C. et al. (eds.) Environmental Biotechnology: For Sustainable Future. Springer, Singapore, pp. 103-125.

[16] Moral, R., Cortés, A., Gomez, I., Mataix-Beneyto, J. (2002): Assessing changes in Cd phytoavailability to tomato in amended calcareous soils. - Bioresource Technology 85(1): 63-68.

[17] Obata, H., Umebayashi, M. (1993): Production of SH compounds in higher plants of different tolerance to Cd. - Plant and Soil 155(1): 533-536.

[18] Peksüslü, A. (1998): Morphological, physiological and biochemical properties of some tobacco types in İzmir-Bornova conditions. - PhD Thesis. Ege University Science Inst. Bornova, Izmir.

[19] Pereira, B. F. F., Rozane, D. E., Araújo, S. R., Barth, G., Queiroz, R. J. B., Nogueira, T. A. R. Malavolta, E. (2011): Cadmium availability and accumulation by lettuce and rice. Revista Brasileira de Ciência do Solo 35(2): 645-654.

[20] Quezada-Hinojosa, R., Föllmi, K. B., Gillet, F., Matera, V. (2015): Cadmium accumulation in six common plant species associated with soils containing high geogenic cadmium concentrations at Le Gurnigel, Swiss Jura Mountains. - Catena 124: 85-96.

[21] Ramos, I., Esteban, E., Lucena, J. J., Gárate, A. (2002): Cadmium uptake and subcellular distribution in plants of Lactuca sp. Cd-Mn interaction. - Plant Sci. 162: 761-767.

[22] Rizwan, M., Ali, S., Adrees, M., Rizvi, H., Zia-ur-Rehman, M., Hannan, F., Ok, Y. S. (2016): Cadmium stress in rice: toxic effects, tolerance mechanisms, and management: a critical review. - Environmental Science and Pollution Research 23(18): 17859-17879.

[23] Sharma, A., Kumar, V., Shahzad, B., Ramakrishnan, M., Sidhu, G. P. S., Bali, A. S., Bakshi, P. (2019): Photosynthetic response of plants under different abiotic stresses: a review. - Journal of Plant Growth Regulation. https://doi.org/10.1007/s00344-01910018-x.

[24] Socha, P., Bernstein, N., Rybanský, Ĺ., Mészáros, P., Gálusová, T., Spieß, N., Matuš́iková, I. (2015): Cd accumulation potential as a marker for heavy metal tolerance in soybean. - Israel Journal of Plant Sciences 62(3): 160-166.

[25] Stolt, J. P., Sneller, F. E. C., Bryngelsson, T., Lundborg, T., Schat, H. (2003): Phytochelatin and cadmium accumulation in wheat. - Environmental and Experimental Botany 49(1): 21-28.

[26] Sun, H., Wang, X., Shang, L., Zhou, Z., Wang, R. (2017): Cadmium accumulation and its effects on nutrient uptake and photosynthetic performance in cucumber (Cucumis sativus L.). - Philippine Agricultural Scientist (Philippines) 100(3): 263-270.

[27] Vasiliadou, S., Dordas, C. (2009): Increased concentration of soil cadmium affects on plant growth, dry matter accumulation, $\mathrm{Cd}$, and $\mathrm{Zn}$ uptake of different tobacco cultivars (Nicotiana tabacum L.). - International Journal of Phytoremediation 11(2): 115-130.

[28] Vázquez, M. D., Poschenrieder, C. H., Barceld, Y. (1992): Cadmium in bean roots. New Phytologist 120(2): 215-226.

[29] Wang, A., Wang, M., Liao, Q., He, X. (2016): Characterization of Cd translocation and accumulation in 19 maize cultivars grown on Cd-contaminated soil: implication of maize cultivar selection for minimal risk to human health and for phytoremediation. Environmental Science and Pollution Research 23(6): 5410-5419. 
[30] Willers, S., Gerhardsson, L., Lundh, T. (2005): Environmental tobacco smoke (ETS) exposure in children with asthma-relation between lead and cadmium and cotinine concentrations in urine. - Respir. Med. 99: 1521-1527.

[31] Zorrig, W., Cornu, J. Y., Maisonneuve, B., Rouached, A., Sarrobert, C., Shahzad, Z., Berthomieu, P. (2019): Genetic analysis of cadmium accumulation in lettuce (Lactuca sativa). - Plant Physiology and Biochemistry 136: 67-75. 